\title{
Analysis of Exhaust Gas Emission from Gasoline- and Diesel-powered Vehicles in Sleman Regency, Indonesia 2019
}

\author{
Marsyaelina $\mathrm{A}^{1, *}$, Z. Arifin ${ }^{2}$, Sutiman ${ }^{2}$, M. Solikin ${ }^{2}$, R. Iskandar ${ }^{1}$ \\ ${ }^{1}$ Technological and Vocational Education, Yogyakarta State University, Indonesia, \\ ${ }^{2}$ Automotive Engineering Education, Yogyakarta State University, Indonesia \\ *Corresponding author: Anggie0302pasca.2018@student.uny.ac.id
}

Received October 21, 2019; Revised December 05, 2019; Accepted December 21, 2019

\begin{abstract}
Vechiles emit large amounts of emissions in towns of developing countries. This study is descriptive research. Analyzer gas as well as opacity were used to collect the necessary data. The objects of the study were motorized diesel engine as well as gasoline engine of various brands that operated around Sleman, a regency in Special Region of Yogyakarta, Indonesia. Those vehicles produce three main exhaust gases: CO, HC, and PM. The largest CO emissions, with figure reaching 6.92\%, come from gasoline-powered Suzuki units released in 1993. Daihatshu units released in 1993 emit the largest HC emissions up to 538 ppm. Meanwhile, diesel-powered vehicles that produce the most Particulate Matter come from Mitsubishi that were released in 2008, with figure reaching 64.55\%.HSU. The analysis of exhaust gas emissions will encourage vehicle owners who haven't yet passed their emission test to do regular maintenance as well as put the right type of fuel into their vehicles.
\end{abstract}

Keywords: CO, diesel-powered vehicle, emissions, exhaust gases, gasoline-powered vehicle, HC, particulate matter

Cite This Article: Marsyaelina A, Z. Arifin, Sutiman, M. Solikin, and R. Iskandar, "Analysis of Exhaust Gas Emission from Gasoline- and Diesel-powered Vehicles in Sleman Regency, Indonesia 2019.” American Journal of Mechanical Engineering, vol. 7, no. 4 (2019): 195-200. doi: 10.12691/ajme-7-4-6.

\section{Introduction}

Sleman Regency is situated in Special Region of Yogyakarta and is known as the center of education, trade, and service [1]. Loads of people are always headed here either to work or to study. This continuous influx of people inevitably results in constant increase of vehicles on the road. As a matter of fact, the Central Bureau of Statistics Sleman reported that there was a definite increase of motor vehicles in 2006 up to 148.424 units in Sleman Regency. With the influx of motor vehicles, emissions from all those vehicles increase and become the major source of air pollution [2].

Unsurprisingly, people begin to voice out their protest following the decline of air quality in Special Region of Yogyakarta. Face masks are now commonly used to reduce exposure to air pollutants when they are on the corner of the road. This phenomenon can only mean two things: that the severity of air pollution has become too much; and that public awareness of air pollution has improved quite drastically [3]. The local government states that ambient air quality in 1997 in Special Region of Yogyakarta was more due to the fact of transportation rather than manufacturing related forms of activity [4].
Gasoline-powered vehicle emissions rise the levels of Hydrocarbon (HC), Carbon Monoxide (CO), and Carbon Dioxide (CO2). Meanwhile, diesel motorcycles emit particulate matter (PM) into the air [5]. Prolonged exposure to HC can cause carcinogenic effect [6], narcotic effect, and even can irritate one's mucous membranes. CO also competes with oxygen, which results in oxygen saturation in the blood. Its effect on oxygen binding can even cause suffocation [7]. PM also causes carcinogenic effect, lung deposition, heart attack, and Parkinson's disease [8]. The various risks of exhaust gas have gained huge attention from every corner of society.

Indonesian government has also taken action by imposing a decree addressing the emission standards to old motor vehicle (act No. 6/2006 of the State Minister for the Environment). The decree prescribes that the emission standards of $4.5 \%$ for CO and $1.200 \mathrm{ppm}$ for HC shall be applied to gasoline-powered motor vehicles made before 2007. Vehicles that went into production starting in 2007, on the other hand, apply to $1.5 \%$ for CO and $200 \mathrm{ppm}$ for HC. Meanwhile, emission standards for $70 \%$ particulate matter shall be applied to diesel-powered motorcycles with gross vehicle weight less than 3.5 tons made before 2010 and $40 \%$ for those that went into production after 2010. This law also addresses emission standards of $70 \%$ for PM for diesel-powered vehicles that went into production before 2010 with gross vehicle weight more 
than 3.5 and 50\% for those produced starting in 2010 [9]. Should this law fail to be obliged, then the vehicles are not allowed to operate on the road [10].

The government is trying to improve air quality with a Blue Sky Program. The Blue Sky Program is intended to (1) try to create a working mechanism in controlling airpollution that are both effective and efficient, (2) to achieve a controlled air-pollution condition, (3) to achieve ambient air quality needed for general health of human being and other living things, (4) to create an environmentally-aware community. One of the source of pollution in the air is motor vehicles [11]. There are technical, administrative, and legal ways that can be done to the manufacturers, dealers, fuel companies, and the drivers themselves to overcome vehicle-induced pollution [12].

Based on the problem of the study mentioned above, this paper will describe (1) the number of vehicles that pass or do not pass emissions test, (2) the brands of gasoline-powered motorcycles that emit the most $\mathrm{CO}$ and HC, and (3) the brands of diesel-powered motor vehicles that contribute particulate matter the most.

In Indonesia, there are up to 13 brands of vehicles produced domestically. They are Toyota, Hino, Hyundai, Honda, Suzuki, Kia, Nissan, Mercedes-Benz, Isuzu, Daihatsu, Mitsubishi, BMW, and Chery [13]. The manufacturing companies always strive to come up with environmentally-friendly technology, such as Exhaust Gas Circulation (EGR), Direct Injection System, homogeneous combustion, particulate filters, and catalytic converter [14]. The implementation of such environmentally-friendly technology on motor vehicles is in fact palpable. In 2013, there was a decrease in air quality in Sleman Regency [16]. Meanwhile in 2019, ambient air in Sleman Regency was somewhere around 70 - 80 according to Air Quality Index, which was considered good [17]. This thing could mean that there is indeed an increase in air quality because of those environmentally-friendly technology.

\section{Methods}

This research employed a quantitative-descriptive approach. The objects of the study were gasoline-powered and diesel-powered motor vehicles operating around Sleman Regency. Representatives were chosen by using random sampling technique and the samples chosen were as follows: Daihatsu, Honda, Suzuki, and Toyota as well as diesel-powered vehicles such as Isuzu, Hino, Toyota, and Mitsubishi. This research took place in Denggung, Sleman Regency on April 10, 2019 by referring to the Indonesian National Standardization (SNI 19-7118.1-2005 and SNI 19-7118.2-2005).

The measurement procedure for gasoline-powered vehicles were based on SNI 19-7118.1-2005 [18] that states the following regulations:

1) Preparations for vehicle testing shall be done as follows: (a) the vehicle that is about to be measured for emissions composition must be parked in an even surface. (b) exhaust pipe is not leaking. (c) The engine must be at normal operating temperature state between $60^{\circ} \mathrm{C}$ and $70^{\circ} \mathrm{C}$ or as recommended by the manufacturer. (d) The accessories system must be turned off. (e) The temperature at workplace should be between $20^{\circ} \mathrm{C}$ and $35^{\circ} \mathrm{C}$.

2) Equipment preparations for emission test for gasoline-powered vehicles, gas analyzer, must be done like the following: (a) Make sure all the tools are properly calibrated. (b) Turn them on according to the standard operating procedure.

3) Evaluation for $\mathrm{CO}, \mathrm{CO} 2$, and $\mathrm{HC}$ composition must be done by following these steps: (a) Prepare the vehicle that is about to be tested. (b) Prepare the testing equipment. (c) Raise the engine speed to $2.900 \mathrm{rpm}$ until $3.100 \mathrm{rpm}$ then hold steady for 60 seconds and then return it to its idle speed. (d) Then do an emission check in its idle state while running the engine at a speed of $600 \mathrm{rpm}$ up to $1000 \mathrm{rpm}$ or as recommended by the manufacturer. (e) At this point, do a probe test inside the exhaust pipe to a depth of $30 \mathrm{~cm}$. If the depth of the exhaust pipe is less than $30 \mathrm{~cm}$ then an additional pipe may be attached. (f) Wait for 20 seconds and collect the data.

Meanwhile, the measurement procedure for diesel-powered vehicles according to SNI 19-7118.2-2005 [19] are as follows:

1) Preparations for vehicle testing shall be done as follows: (a) the vehicle that is about to be measured for emissions composition must be parked in an even surface. (b) The exhaust pipe is not leaking. (c) The engine must be at normal operating temperature state between $60^{\circ} \mathrm{C}$ and $70^{\circ} \mathrm{C}$ or as recommended by the manufacturer. (d) The accessories system must be turned off. (e) The temperature at workplace should be between $20^{\circ} \mathrm{C}$ and $35^{\circ} \mathrm{C}$.

2) Equipment preparations for emissions test for diesel-powered vehicles, smoke opacimeter, shall be done as follows: a) Make sure the tool is properly calibrated; b) turn it on according to the standard operating procedure (according to manufacturer's recommendation).

3) Smoke opacity test shall use smoke opacimeter by following these steps: (a) Prepare the vehicle that is about to be tested. (b) Prepare the testing tools. (c) Raise the engine speed to $2.900 \mathrm{rpm}$ until 3.100 rpm then hold steady for 60 seconds and then return it to its idle speed. (d) Then do an emission check on the exhaust pipe by probing as far as $30 \mathrm{~cm}$, if the depth is less than $30 \mathrm{~cm}$ then an additional pipe may be attached. (e) the accelerator control shall be operated quickly but not violently in order to obtain maximum delivery from the injection pump. Maintain this position until the engine reaches its maximum speed, then hold steady for one to four seconds before releasing the pedal and the engine resuming to its idling speed. Take a note of the smoke opacity value. (f) Repeat step (e) at least three times. (g) Take a note of the average percentage value of smoke opacity in step (f) in a percentage unit (\%) as measured on the testing tool. 


\section{Result and Discussion}

\subsection{Analysis on the Comparison between Exhaust Emission and Emissions Standards}

The total of vehicles that underwent an emission test reached 133 units for BMW, Daihatsu, Datsun, Honda Hino, Hyundai, Isuzu, Kia, Mitsubishi, Nissan, Suzuki, and Toyota. Out of 133 units, a total of 17 vehicles were Daihatsus, 13 Hondas, 12 Suzukis, and 37 Toyotas. Meanwhile, diesel-powered vehicles like Mitsubishi reached a total number of 19 units, 9 units for Toyota. and 5 units each for Hino and Isuzu.

The emissions test results of the aforementioned vehicles were then compared with emissions standards. The comparison results can be seen in Table 1 .

Table 1. Results of Comparison between Vehicles emissions and Emissions Standards

\begin{tabular}{|c|c|c|c|}
\hline \multirow{2}{*}{$\begin{array}{c}\text { Production } \\
\text { Year }\end{array}$} & \multirow{2}{*}{$\begin{array}{c}\text { Sample } \\
\text { Number }\end{array}$} & \multicolumn{2}{|c|}{ Test Results } \\
\cline { 3 - 4 } & Passed & Did not Pass \\
\hline $2019-2015$ & 46 & 36 & 4 \\
\hline $2014-2010$ & 41 & 32 & 6 \\
\hline $2009-2005$ & 9 & 8 & 1 \\
\hline $2004-2000$ & 12 & 12 & 1 \\
\hline $1999-1995$ & 3 & 3 & 0 \\
\hline $1994-1989$ & 6 & 5 & 1 \\
\hline Sum & 117 & 104 & 13 \\
\hline \multicolumn{2}{|c|}{ Average } & $88.89 \%$ & $11.11 \%$ \\
\hline
\end{tabular}

As can be seen from Table 1, it is clear that there is $11.11 \%$ of vehicles that did not pass the emission test. There are several factors that contribute to this: putting the wrong type of fuel in the vehicles; and failure to do regular maintenance. The unmatched values of RON and compression ration caused the gasoline to get burnt by the temperature in the cylinder before it is ignited by the spark plugs in the gas engine [20]. Moreover, the cetane number that does not match the specification also increased opacity production [21]. To find out the correct type of fuel that the vehicle needs, one can read the brochure that comes when purchasing the vehicle.

People tend to not realize the importance of taking care of their newly-bought vehicles, or even if they do their awareness of it is still very low. It is indicated from when four out of 46 vehicles released in 2015 - 2009 did not pass the emission test. Moreover, the vehicle owners also failed to do regular vehicle service. Such maintenance is needed in order to keep the vehicle functioning properly and optimally, including the emission it emits [22].

\subsection{Gasoline Powered Vehicles}

1) Daihatsu Brands

Figure 1 shows that Daihatshu released in 2002 contributed the most when it comes to CO emissions, with figure reaching $0.76 \%$. Meanwhile, Figure 2 shows that the largest emissions of $\mathrm{HC}$ comes from Daihatshu released in 2002, with figure reaching 375 ppm.

2) Honda Brands

Figure 3 shows that the largest CO emissions (1.53\%) come from Daihatshu products released in 2002 while Figure 4 shows that Daihatshu released in 1990 contributed 312 ppm to the largest HC emissions category.

3) Suzuki Brands

Figure 5 shows that the largest CO emissions come from SUzuki released in 1993, with figure reaching 6.92\% while Figure 6 shows that the Daihatsu released in 1993 contributed the most to HC emissions with 538 ppm.

4) Toyota Brands

Figure 7 shows that the largest CO emissions come from Daihatsu released in 2013 (up to 0.56\%) while Figure 8 shows that Daihatshu released in 1990 emitted the largest HC emissions up to 174.28 ppm.

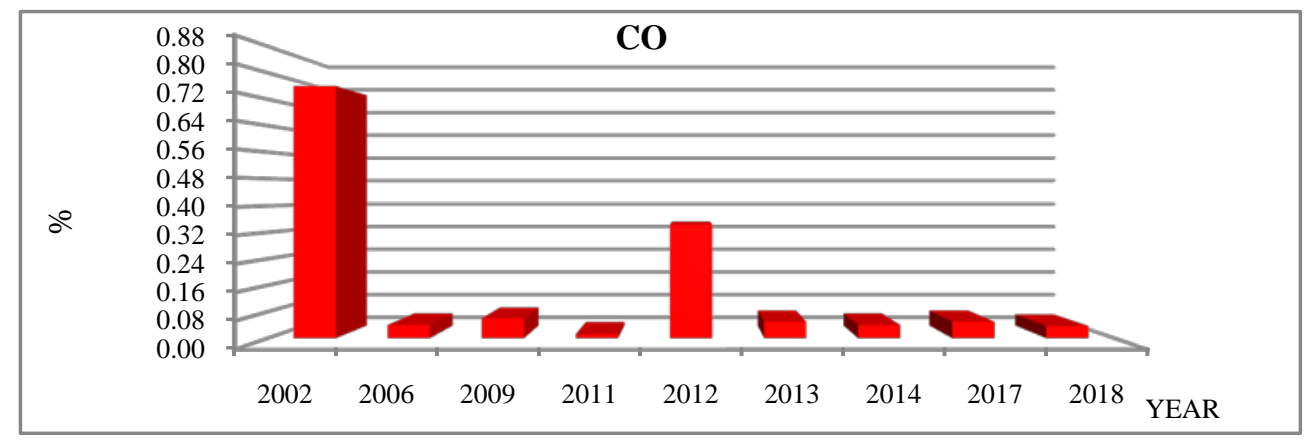

Figure 1. CO emitted from Daihatsu Brands

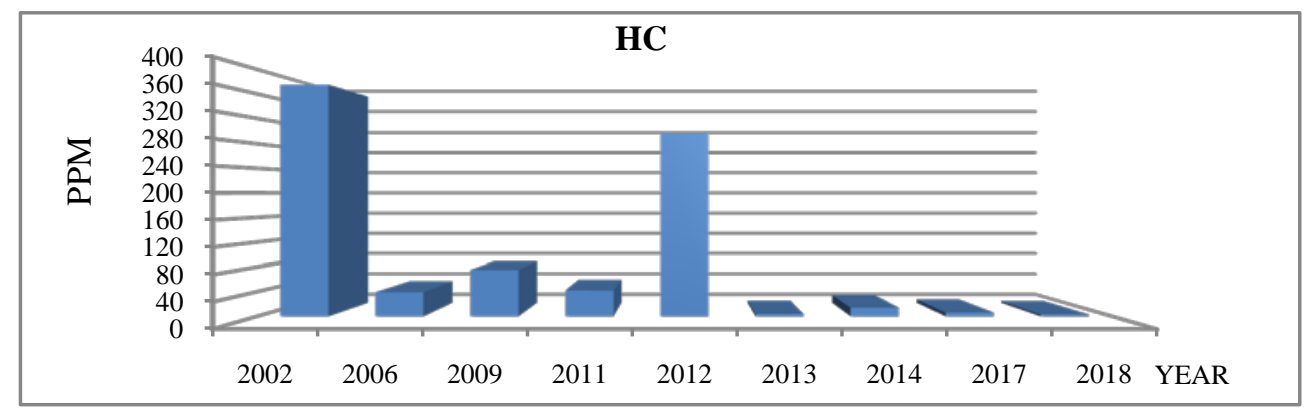

Figure 2. HC emitted from Daihatsu Brands 


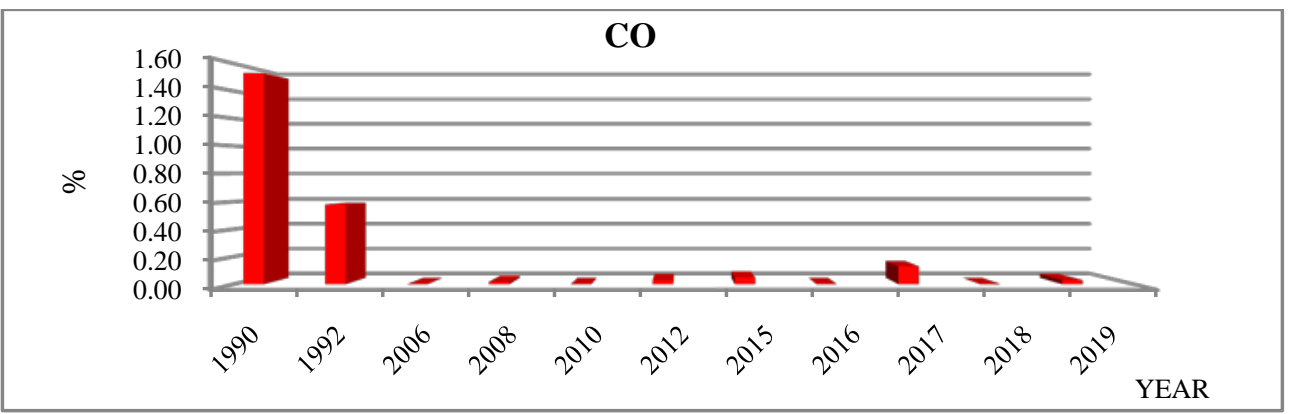

Figure 3. CO emitted from Honda Brands

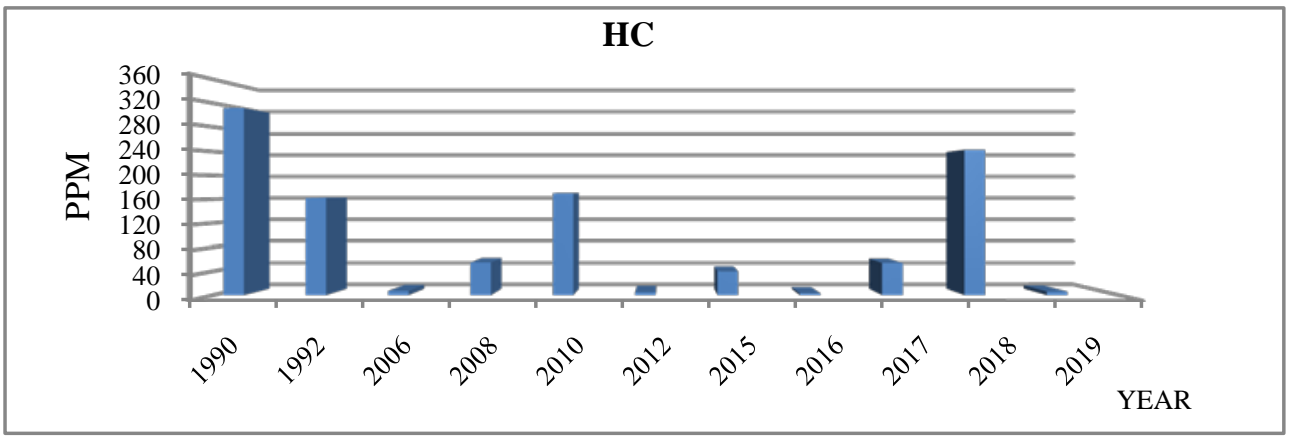

Figure 4. HC emitted from Honda Brands

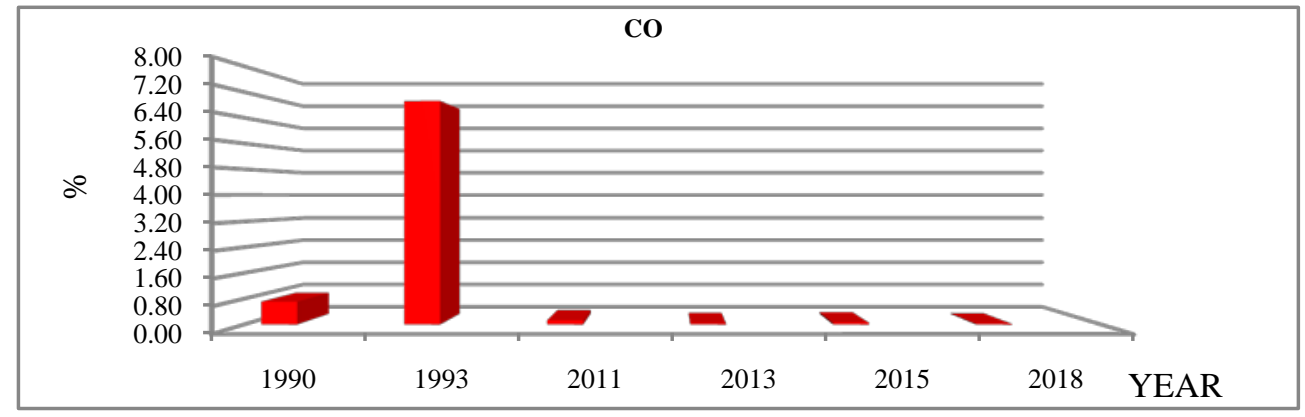

Figure 5. CO emitted from Suzuki Brands

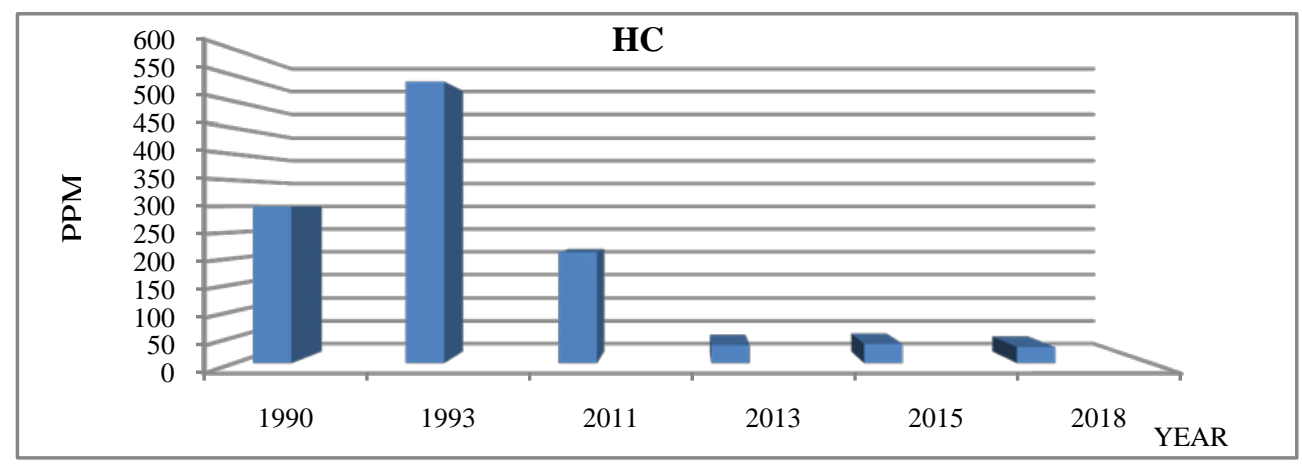

Figure 6. HC emitted from Suzuki Brands

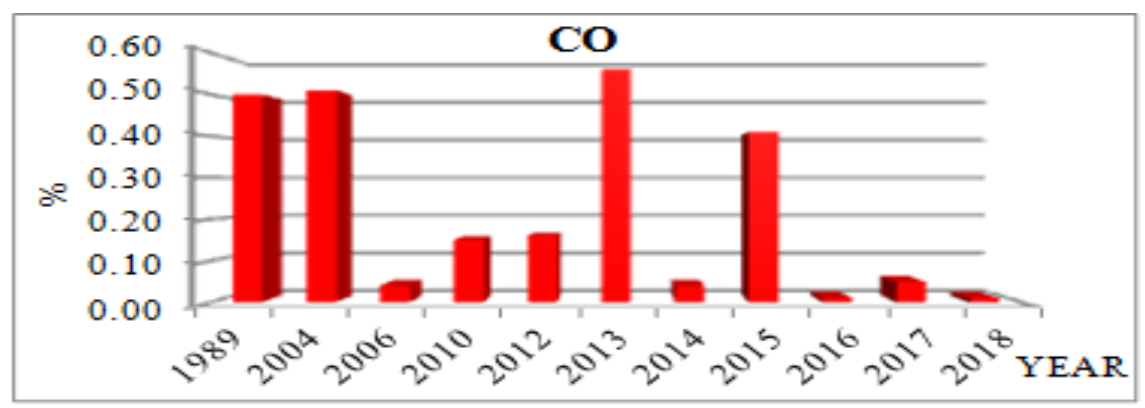

Figure 7. CO emitted from Toyota Brands 


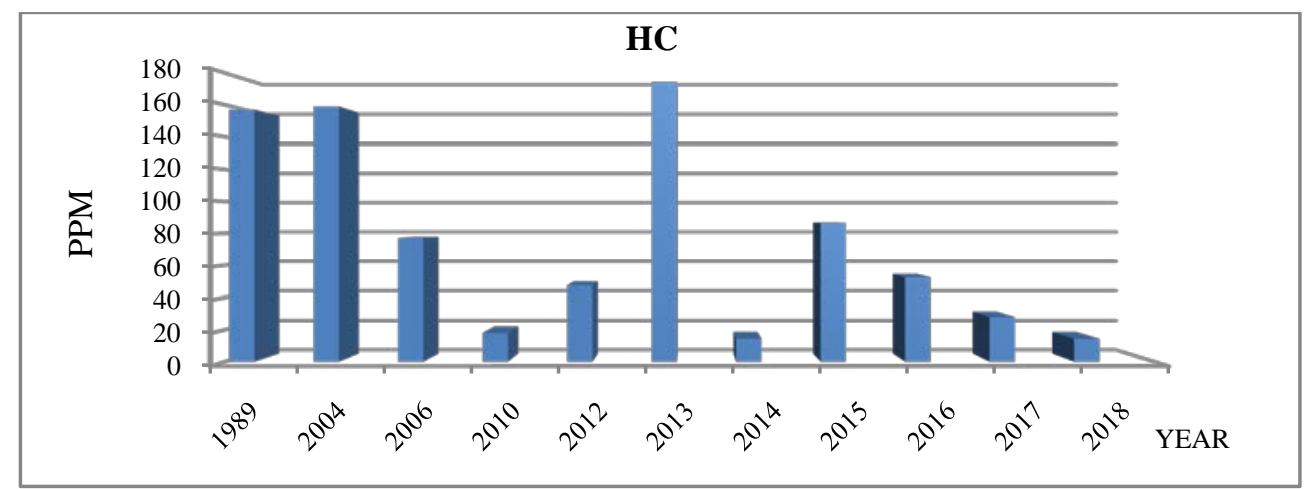

Figure 8. HC emitted from Toyota Brands

Out of the four brands, the largest CO emissions come from Suzuki released in 1993, with figure reaching 6.92\% while Daihatshu released in 1993 contributed the largest HC emissions (up to 538 ppm).

Complete combustion produces carbon dioxide. Carbon Monoxide emits into the air because there is insufficient oxygen to completely combust the fuel and inadequate temperature level. To reduce CO emissions, then excess air is needed [21,23]. Hydrocarbon occurs when a fuel begins burning before the spark plug has the chance to ignite it. However, most of the time it happens because of delayed fuel delivery into the combustion chamber and the gasoline fails to evaporate due to the engine's temperature. Consequently, the fuel combustion does not take place and gets out into the air as droplets. [23].

\subsection{Diesel Powered Vehicles}

1) Hino Brands

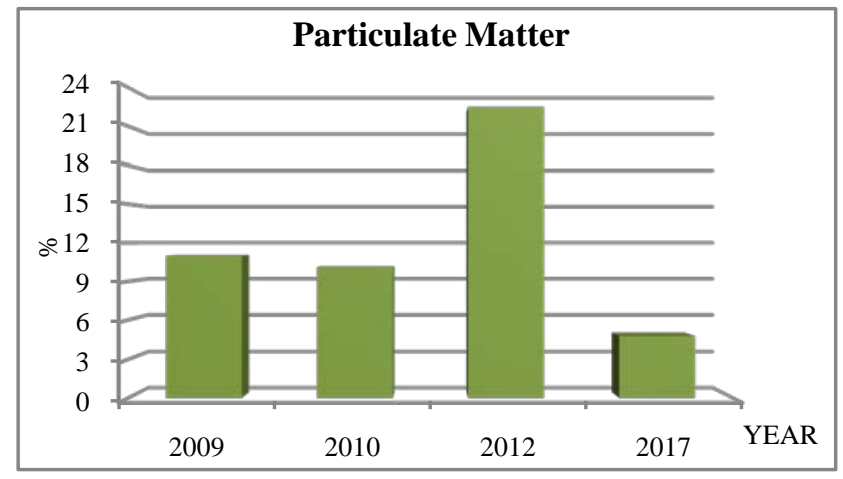

Figure 9. Particulate Matter emitted from Hino Brands

Figure 9 shows that Hino released in 2012 produces the largest particulate matter into the air as much as $22.5 \%$. a. Isuzu Brands

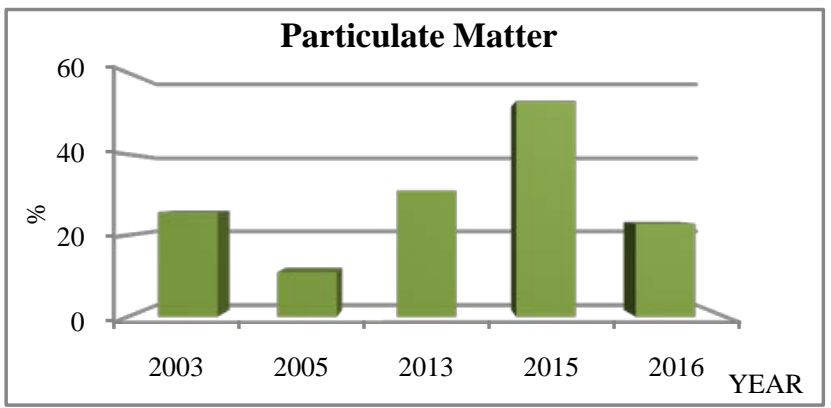

Figure 10. Particulate Matter emitted from Isuzu Brands
Figure 10 shows that the largest particulate matter emissions come from Isuzu released in 2015, with figure reaching 53\%.

2) Mitsubishi Brands

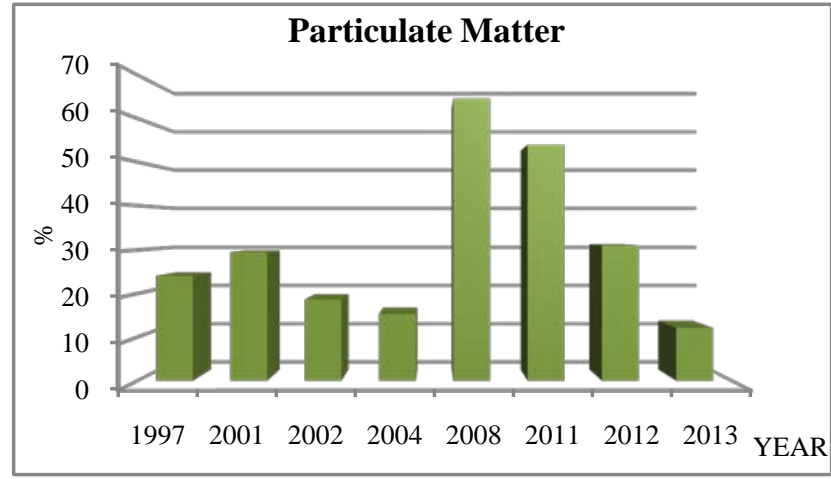

Figure 11. Particulate Matter emitted from Mitsubishi Brands

Figure 11 shows that Mitsubishi releaed in 2008 emits the largest particulate matter amounting to $64.55 \%$.

3) Toyota Brands

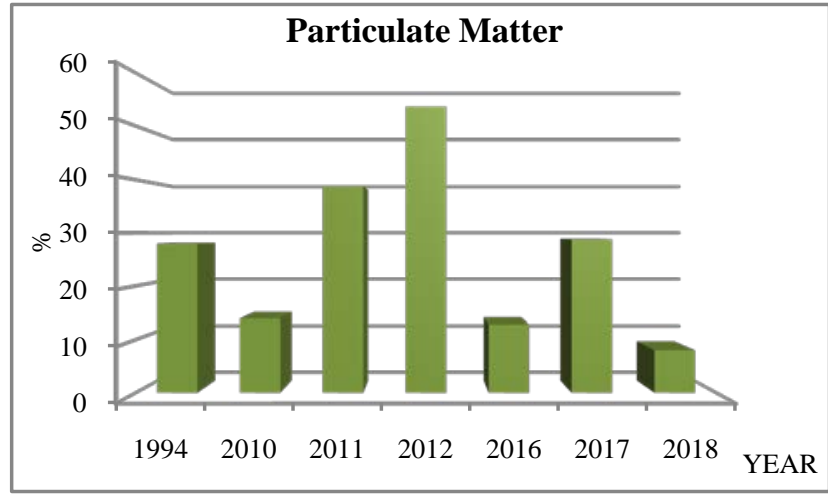

Figure 12. Particulate Matter emitted from Toyota Brands

Figure 12 shows that Toyota released in 2012 produces the largest particulate matter up to $53.70 \%$.

Out of the four brands mentioned above, Mitsubishi units released in 2008 emit the largest particulate matter up to $64.55 \%$. This shows that not all vehicles around 11 years of age can pass an emission test.

The cause of particulate matter can be analyzed from smoke. white smoke indicates unburned diesel fuel in the exhaust gas. Blue smoke indicates irregular maintenance done to the vehicle and too small an amount of lubricating oil. Black smoke, on the other hand, indicates incomplete combustion [23]. 


\section{Conclusion}

Gasoline-powered motor vehicles that emit the largest CO, amounting to $6.92 \%$, belong to Suzuki units released in 1993 while Daihatshu units released in 1993 emit the largest HC, up to 538 ppm. Meawhile, Diesel-powered motor vehicle that produce the largest PM, up to 64.55\%.HSU, belong to Mitsubishi units released in 2008. It is recommended for all vehicle owners who passed emission test to put the right type of fuel into their vehicles along with doing regular vehicle service.

\section{References}

[1] Sleman Goverment. (2019). Regional Characteristics. [Online] Available: http://www.slemankab. go.id.

[2] Sleman Central Bureau of Statistics. (2017). The Number of registered Vehicles according to the types in Sleman Regency expected Military Vehicles in 2015-2016 Available: https://slemankab.bps.go.id.

[3] Winarni, F. (2006). Kebijakan Program Langit BIru dalam Rangka Pengendalian Pencemaran Udara. Jurnal Mimbar Hukum XVIII(1) page 144.

[4] Bantul Enviromental Agency. (2012). Laporan Pemantauan Kualitas Udara Tahun 2012. Available: https://dlh.bantulkab.go.id /filestorage/dokumen/2014/07/Buku\%20Kualitas\%20Udara\%2020 12.pdf .

[5] Transportation Research Board, National Research Council. (2002). The Congestion Mitigation and Air Quality Improvement Program, Assessing 10 Years of Experience; pp. 60-4.

[6] Audi. Motor Vehicle Exhaust Emissions: Composition, emission control, standards, etc. Wolfsburg: VOLKSWAGEN AG. Available: www.volkspage.net/ technik/ssp/ssp/SSP_230.pdf.

[7] Schäfer, F., \& Van, B. R. (1995). Reduced emissions and fuel consumption in automobile engines. Wien: Springer-Verlag.

[8] Pihlava, T. Uuppo, M. and Niemi, S. (2012). Proceedings of the University of Vaasa Reports 187. Vaasan yliopisto - University of Vaasa.

[9] Ministry of Environment and Forestry Republic of Indonesia. (2006). Regulation of Ministry of Environment Number 6 in 2006 concerning on Threshold of Vehicles Emissions for Old Motor Vehicles
[10] Indonesian Government. (2009). Law of Republic of Indonesia Number 22 in 2009 concerning on the Land Traffic and Transport.

[11] Ministry of Environment and Forestry Republic of Indonesia. (1996). Regulation of Ministry of Environment Number 15 in 1996 concerning on Blue Sky Program (Program Langit Biru).

[12] Yogyakarta Special Region Governor. Decree of the Governor of the Special Province of Yogyakarta Number 182 in 2003 concerning on Blue Sky Program in Yogyakarta Special Region Province.

[13] Ministry of Trade and Industry of Indonesia. Kinds and types of 4wheeled motorized vehicles in domestic production. [Online]. Available: http://www.kemenperin.go.id

[14] Haum, R. and Petschow U. (2003). Lead Markets for Environmental Technologies: The Case of the Particulate Filter for Diesel Passenger Cars. Institut für ökologische Wirtschaftsforschung, Diskussionspapier 59/03. (Online). Available: https://pdfs.semanticscholar.org

[15] Arifin, Z. and Sukoco. (2009). Pengendalian Polusi Kendaraan. Bandung: Alfabeta.

[16] Sleman Goverment. (2013). Regional Environmental Status Report of Sleman Regency in 2013. (Online). Available: http://blh.jogjaprov.go.id.

[17] KRjogja.com. (2019). Kualitas Udara Sleman Baik dan Layak. (Online). Available: https://krjogja.com.

[18] National Standardization Agency of Indonesia. (2005). SNI 097118. 1-2005: Exhaust gas emissions - Movable source - Part 1: Test methods of motor vehicles category $\mathrm{M}, \mathrm{N}$ and $\mathrm{O}$ having a motivator lighter ignition at idle condition. (Online). Available: http://sispk.bsn.go.id.

[19] National Standardization Agency of Indonesia. (2005). SNI 097118.2-2005: Exhaust gas emissions - Movable source - Part 2: Test methods of motor vehicles category $\mathrm{M}, \mathrm{N}$ and $\mathrm{O}$ having a motivator compression ignition at free acceleration condition. (Online). Available: http://sispk.bsn.go.id.

[20] Ayala, F. A., Gerty, M. D., and Heywood, J. B. (2006). Effects of Combustion Phasing, Relative Air-fuel Ratio, Compression Ratio, and Load on SI Engine Efficiency. Detroit: SAE Technical Paper Series.

[21] Arifin, Z and Sukoco. (2009). Pengendalian Polusi Kendaraan. Bandung: Alfabeta.

[22] Solikin, M. (1997). Dampak dan Upaya Mengedali Gas Buang Kendaraan Bermotor. Cakrawala Pendidikan. No. 3 XVI.

[23] Eckert, P. and Rakowski, S. (2012). Pollutant Formation. In Merker, G. P., Schwarz, C., Teichmann, R. (eds.), Combustion Engines Development. Berlin: Springer-Verlag.

[24] Eastwood, P. (2008). Particulate Emissions from Vehicles. Chichester, West Sussex: John Wiley \& Sons, Ltd. 